\title{
SUBFERTILITY BEFORE AND AFTER THE DEVELOPMENT OF RHEUMATOID ARTHRITIS IN WOMEN
}

\author{
BY \\ APRIL KAY AND FRANCIS BACH \\ From the Chelsea and Kensington Group Rheumatism Units, St. Stephen's Hospital, London
}

Hargreaves (1958), in a study of a population in Cornwall, England, noticed that a group of women with rheumatoid arthritis had fewer children than a control group without this disease.

Independently, at this Unit, we have noticed that, of the large number of married women attending with rheumatoid arthritis, the majority had few children or none at all. Accordingly a controlled study was undertaken of fertility and related factors in women before and after the development of their rheumatoid arthritis.

\section{Material}

Women with rheumatoid arthritis were included if the following conditions were observed:

(1) Their disease fulfilled the American Rheumatism Association criteria for "classical" or "definite" rheumatoid arthritis (Ropes, Bennett, Cobb, Jacox, and Jessar, 1959);

(2) They had first attended the Rheumatism Unit between January 1, 1950, and December 30, 1959;

(3) They were living within a 4-mile radius of St. Stephen's Hospital at the time of the survey.

Of 209 patients thus assembled, 98 had developed rheumatoid arthritis before the menopause and 111 after the menopause.

Control subjects were found from the lists of patients registered with seventeen general practitioners in contract with the National Health Service within a 4-mile radius of St. Stephen's Hospital. The control was not necessarily registered with the same general practitioner as the corresponding rheumatoid subject.

Patients and controls were matched by the following method. Each general practitioner's surgery file was consulted and a list of female names was collected in alphabetical order starting at any convenient point in the alphabet. All consecutive female names encountered were added to this list together with the relevant dates of birth and addresses.
These "potential control" subjects were then stratified for age in 10-year groups and for economic status by the $\mathrm{J}$-index.

The J-index (Gray, Corlett, and Frankland, 1950; Gray, Corlett, and Jones, 1951) is an expression of the percentage of jurors to the total electorate in any given area, as found in the electoral roll. A juror being a man of substance, a high $\mathrm{J}$-index is found in more prosperous areas. The unit of area used in this survey was in most instances the street of residence, but large blocks of flats were considered separately from the streets in which they stood, wherever modern flats had been erected in an area of poor quality houses. The first "potential control" to have the same classification for age and economic status as one of the patients with rheumatoid arthritis was regarded as the matched control to that patient. The procedure was repeated until each rheumatoid patient was paired with a control. A letter was written to the control subjects asking them to agree to be interviewed, but no details of the object of the study were given. Enclosed with the letter was a simple reply form and a stamped addressed envelope; 170 ( 82 per cent.) of the controls first selected agreed to be interviewed. The remaining controls were found at random by the same method but represented a second choice.

\section{Methods}

All patients included in the survey were interviewed by one of us at a routine outpatient attendance or, if not still attending hospital, in their own homes. Eight patients were not willing to co-operate and nineteen others had moved out of the area covered by the survey. The majority of the controls were interviewed in their own homes except for the few who wished to come to the hospital.

Rheumatoid patients and controls were asked to state their religion, date of birth, and age at menarche, marriage, and menopause, as well as the number, age and sex of their children. Those married were asked whether or not they had at any time used any method of 
birth control. Rheumatoid patients were asked at what age they first had symptoms of arthritis; in most of them this could be confirmed from the case notes. The order and manner in which the questions were presented was kept as uniform as possible. Eighteen of the rheumatoid patients were interviewed for a second time by an independent observer (Dr. B. M. Ansell) who obtained substantially the same results as had been noted in the first interviews.

\section{Results}

The women who developed rheumatoid arthritis before the menopause are referred to as Group I and the findings in this group are considered separately from those of the women who developed rheumatoid arthritis after the menopause and who are referred to as Group II.

Age at menarche and marriage (Table I) and also religion were comparable in patients and controls in both groups. The sex distribution of the children of patients and controls were also comparable. Amongst those aged 50 or more at the time of the survey, the onset of menstruation had been rather later than in the younger women, which is consistent with the trend to earlier menarche in the general population. There were more married controls than patients in both groups. In Group I (premenopausal onset) there were eighty married patients and 87 married controls. In Group II (postmenopausal onset) there were 85 married patients and 93 married controls. The mean age at onset of rheumatoid arthritis in Group I was 34.9 years and in Group II 58 years. More controls than patients in both groups admitted to practising some form of birth control (Table I).

\section{Pre-Menopausal Onset (Group I)}

The eighty married women who developed rheumatoid arthritis before the menopause had a total of 128 live births, whereas the 87 married controls had a total of 217 live births. Thus the mean size of family of the married patients in Group I was $1.60 \pm 0.21^{*}$ and that of the married controls $2.49 \pm 0.24$. This difference is significant ( $P<0.01$ ), but an obvious comment would be that it is due to the effect of a chronic and often disabling disease which may reduce physical attractiveness, libido, and the desire to bear children, and in severe cases even make intercourse impossible. A further examination of the data shows that this cannot be the whole explanation. The onset of rheumatoid arthritis in married women before the menopause occurred in the majority after the age of 35 , in the latter part of the childbearing period when it would be unlikely to have a major influence on family size.

Differences caused by the clinical manifestations of rheumatoid arthritis can be excluded by confining our attention to events before its onset. Amongst the 98 pairs were 54 in which both the patient and the control were married before the age at onset of disease in the patient (Table II, opposite). The 54 married patients had a total of 76 live births, whereas their 54 married controls had a total of 124 live births

\footnotetext{
* Mean \pm standard error; this convention will be adopted throughout the paper
}

TABLE I

COMPARISON OF GROUPS

\begin{tabular}{|c|c|c|c|c|c|c|c|}
\hline \multirow{2}{*}{\multicolumn{4}{|c|}{ Onset of Rheumatoid Arthritis }} & \multicolumn{2}{|c|}{ Pre-Menopausal (Group I) } & \multicolumn{2}{|c|}{ Post-Menopausal (Group II) } \\
\hline & & & & Patients & Controls & Patients & Controls \\
\hline Number in series & $\cdots$ & $\cdots$ & $\cdots$ & 98 & 98 & 111 & 111 \\
\hline Mean age at menarche (yrs) & $\cdots$ & $\cdots$ & $\cdots$ & $13 \cdot 7$ (range 9-20) & $13 \cdot 6$ (range $11-18)$ & $14 \cdot 0$ (range $11-18$ ) & $14 \cdot 1$ (range $10-18$ ) \\
\hline Number married. . & $\cdots$ & $\cdots$ & $\cdots$ & 80 & 87 & 85 & 93 \\
\hline Mean age at marriage (yrs) & $\cdots$ & $\cdots$ & $\cdots$ & $25 \cdot 1$ (range $18-38$ ) & $24 \cdot 7$ (range $18-60$ ) & $25 \cdot 9$ (range $16-48$ ) & $25 \cdot 4$ (range $17-58$ ) \\
\hline Number of live births $\ldots$ & $\cdots$ & $\cdots$ & $\cdots$ & 128 & 217 & 155 & 203 \\
\hline Number of abortions $\quad$.. & $\cdots$ & $\cdots$ & $\cdots$ & 25 & 22 & 14 & 26 \\
\hline Number of stillbirths $\quad$. & $\cdots$ & $\cdots$ & $\cdots$ & 3 & 1 & 3 & 6 \\
\hline Number practising birth contr & rol & $\therefore$ & $\cdots$ & 29 & 40 & 22 & 26 \\
\hline Number of Roman Catholics & $\cdots$ & $\cdots$ & $\cdots$ & 16 & 16 & 12 & 9 \\
\hline Mean age at menopause (yrs) & $\cdots$ & $\cdots$ & $\cdots$ & $48 \cdot 3$ (range $42-54$ ) & $49 \cdot 8$ (range 44-60) & $46 \cdot 6$ (range $32-56$ ) & $49 \cdot 4$ (range $42-54$ ) \\
\hline $\begin{array}{l}\text { Mean age at onset of } \mathrm{Rheuma} \\
\text { (yrs) } \begin{array}{lll} \\
\text { (y }\end{array}\end{array}$ & $\begin{array}{l}\text { atoic } \\
\cdots\end{array}$ & $\cdots$ & $\cdots$ & $34 \cdot 9$ (range $17-52$ ) & - & $58 \cdot 0$ (range $42-80)$ & - \\
\hline Mean age at time of survey (y & yrs) & . & $\cdots$ & $49 \cdot 4$ (range $28-80$ ) & $49 \cdot 5$ (range $23-78$ ) & $64 \cdot 8$ (range $44-88)$ & $64 \cdot 5$ (range $41-89$ ) \\
\hline
\end{tabular}


before the age of onset of disease in the patient. Thus the mean size of family at onset of disease in these 54 pairs was $1.40 \pm 0.19$ for patients and $2 \cdot 29 \pm 0.24$ for their matched controls. This difference is significant $(P<0 \cdot 025)$.

TABLE II

FERTILITY IN 54 PAIRS IN WHICH BOTH PATIENT AND CONTROL WERE MARRIED BEFORE ONSET OF RHEUMATOID ARTHRITIS IN THE PATIENT

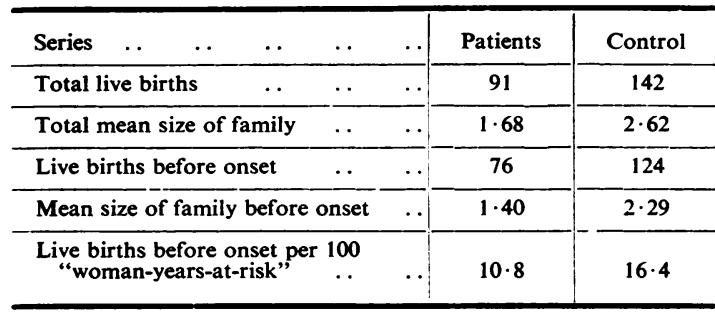

The difference is clearly illustrated in Fig. 1. Thus nineteen of the patients were childless at onset compared with only nine of the controls at the same age. It was also noted that many of those with only one child stated that they had wanted more children. There was a tendency for the patients in Group I to be married later than the controls and this might well account for part of the difference. This can be allowed for by recalculating fertility in terms of the number of births per hundred "womanyears at risk"; this gave 10.8 in the patients compared with 16.4 in the controls: a further indication of the difference between the fertility of subjects and controls.

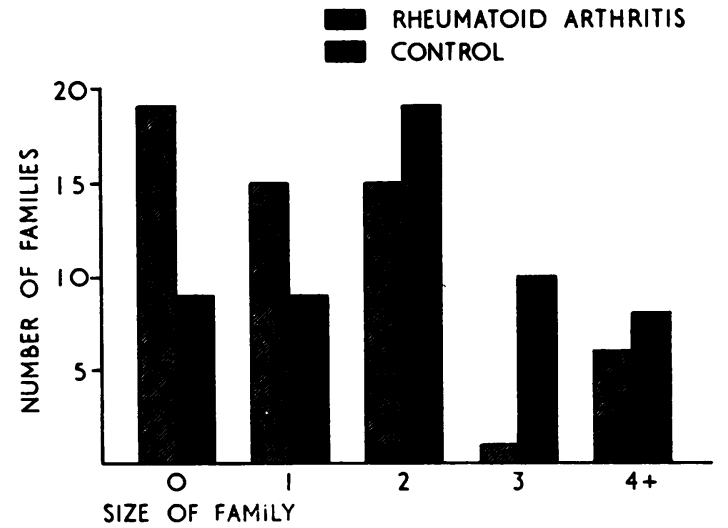

Fig. 1.-Size of family of 54 women with pre-menopausal onset of rheumatoid arthritis and 54 matched controls.

The presence of rheumatoid factor was tested for in seventy out of eighty patients in Group I, by the sheep cell agglutination test (S.C.A.T.). A reciprocal titre of 16 or greater was regarded as positive (Table III). Patients who showed a positive S.C.A.T. at any time were more frequently childless at the time of the survey than those in whom the S.C.A.T. was negative, but this difference had not been apparent at the time of onset of the disease, and may only mean that the more severe disease associated with the presence of rheumatoid factor had caused greater difficulty in conceiving children.

There were comparable numbers of abortions among the patients with pre-menopausal onset of rheumatoid arthritis and their controls, but in the

TABLE III

FERTILITY RELATED TO S.C.A.T. STATUS IN MARRIED WOMEN WITH PRE-MENOPAUSAL ONSET OF RHEUMATOID ARTHRITIS

\begin{tabular}{|c|c|c|c|c|c|c|c|c|c|c|c|c|}
\hline S.C.A.T. . & . & . & . & . & . & . & . & $\cdots$ & Positive & Negative & Not known & Total \\
\hline Number of Su & ets & $\cdots$ & $\cdots$ & $\cdots$ & $\cdots$ & $\cdots$ & $\cdots$ & $\cdots$ & 45 & 25 & 10 & 80 \\
\hline \multirow[b]{2}{*}{ Live Births } & \multicolumn{2}{|c|}{ Total } & . & $\cdots$ & $\cdots$ & $\cdots$ & $\cdots$ & $\cdots$ & 76 & 42 & 10 & 128 \\
\hline & \multicolumn{3}{|c|}{$\begin{array}{l}\text { Before onset } \\
\text { After onset }\end{array}$} & 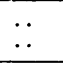 & $\because$ & 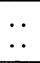 & $\because$ & $\cdots$ & $\begin{array}{l}64 \\
12\end{array}$ & $\begin{array}{l}25 \\
17\end{array}$ & $\begin{array}{l}9 \\
1\end{array}$ & $\begin{array}{l}98 \\
30\end{array}$ \\
\hline \multirow[b]{2}{*}{ Parity } & \multicolumn{2}{|c|}{ Parous } & $\cdots$ & $\cdots$ & $\cdots$ & $\ldots$ & $\cdots$ & $\cdots$ & 31 & 20 & 6 & 57 \\
\hline & \multicolumn{4}{|c|}{$\begin{array}{l}\text { Non-parous } \\
\text { Non-parous at onset }\end{array}$} & 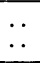 & 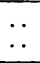 & 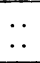 & $\cdots$ & $\begin{array}{l}14 \\
17\end{array}$ & $\begin{array}{r}5 \\
10\end{array}$ & $\begin{array}{l}3 \\
4\end{array}$ & 22 \\
\hline \multirow[b]{2}{*}{ Abortions } & & & $\cdots$ & $\cdots$ & $\cdots$ & $\cdots$ & $\cdots$ & $\cdots$ & 23 & 4 & 2 & 29 \\
\hline & \multicolumn{4}{|c|}{$\begin{array}{l}\text { In parous women ... } \\
\text { In non-parous women }\end{array}$} & $\begin{array}{l}\cdots \\
\cdots\end{array}$ & $\begin{array}{l}\cdots \\
\cdots\end{array}$ & $\begin{array}{l}. \\
\cdots\end{array}$ & $\begin{array}{l}\cdots \\
\cdots\end{array}$ & $\begin{array}{r}19 \\
4 \\
\end{array}$ & 2 & $\begin{array}{l}2 \\
\mathbf{0}\end{array}$ & $\begin{array}{r}23 \\
6\end{array}$ \\
\hline Stillbirths & . & $\cdots$ & . & . & $\cdots$ & $\cdots$ & $\cdots$ & $\ldots$ & 0 & 2 & 1 & 3 \\
\hline
\end{tabular}


rheumatoid women there was a relatively higher incidence of abortion amongst those with a positive D.A.T. (Tables I and III).

The menopausal age of those patients who had already developed rheumatoid arthritis was, on the average, one year less than that of their controls (Table I). This finding is of limited value as only forty members of this group had reached the menopause at the time of the survey.

\section{Post-Menopausal Onset (Group II)}

The 85 married women with rheumatoid arthritis who developed the disease after the menopause had a total of 155 live births, whereas the 93 married controls had 203 live births. Thus the mean size of family of the married rheumatoid women in Group II was $1 \cdot 78 \pm \mathbf{0} \cdot 18$ and that of the controls $2 \cdot 18 \pm 0 \cdot 19$. This difference is not significant ( $P<0.07$ ) but supports the previous trend. Fig. 2 shows a greater disparity between patients and controls with increasing maternal age. 23 per cent. of married women in Group II who were later to develop rheumatoid arthritis had no children compared with 16 per cent. of the control subjects.

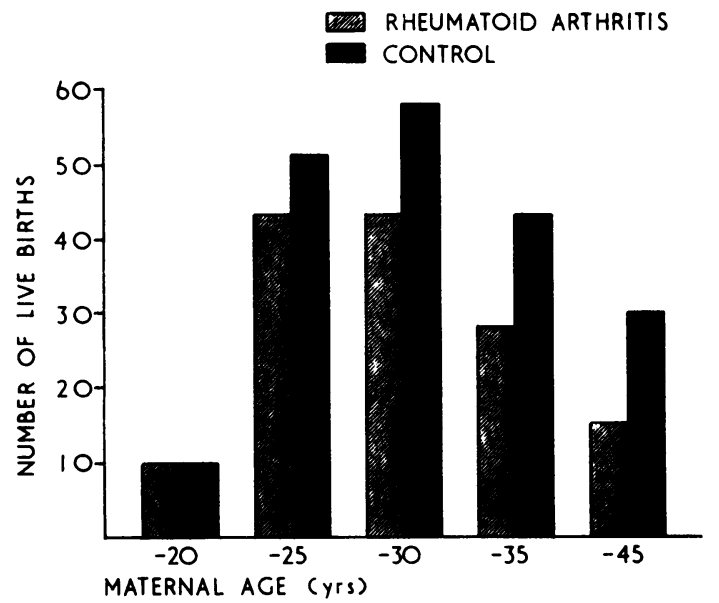

Fig. 2.-Number of children born alive to women with rheumatoid arthrit is of post-menopausal onset and matched controls, by maternal age. (Sixteen live births to rheumatoid patients and 21 to controls

are omitted because date of birth not remembered by family.)

The mean age at the menopause in 79 women who were later to develop rheumatoid arthritis was $46 \cdot 6 \pm 0 \cdot 35$, significantly less than that of their 81 matched controls which was $49.4 \pm 0.18$ ( $P<0.025)$. Patients and controls in which the menopause was the result of surgery or radiation were not included in the analysis of age at menopause nor were there those who could not remember when their menstrual periods ceased. It was noted that eighteen of the women who subsequently developed rheumatoid arthritis had been subjected to hysterectomy or radiation menopause compared with eleven of the control subjects. In at least fourteen of the rheumatoid women ovarian function was known to have been withdrawn by surgery or radiation.

\section{Discussion}

These results indicate that the women in this series who were destined to develop rheumatoid arthritis were subfertile and that their menstrual span was reduced.

There are a number of possible sources of bias in comparing the patients and the control series. It is possible that a slight selective bias could have arisen from the exclusion of nineteen subjects who had left the area, for they might have represented more fertile women who had been able to move out of London because they had grown-up children. However, data from their case notes and from those of the eight patients who were unwilling to co-operate suggest that their reproductive histories are similar to those of rheumatoid women included in the study.

A similar argument might apply to the controls; if subfertility was associated with unwillingness to co-operate with this study, the control group would be deficient in subfertile women. The completion rate for "first choice" controls was only 82 per cent. To correct for this possible source of bias it was assumed that all second choice controls were childless and the data were recalculated; in the 54 pairs (Fig. 2) the difference in mean size of family of patients and controls remained significant $(P<0 \cdot 05)$.

We offer no explanation for our findings, but it is possible that the same mechanism is at work as in women with systemic lupus erythematosus in whom it has been noted by several observers (Ellis and Bereston, 1952; Friedman and Rutherford, 1956; Garsenstein, Pollak, and Kark, 1962; Madsen and Anderson, 1961; Turner, LeVine, and Rothman, 1955) that there is a high incidence of abortion in early pregnancy and an increased incidence of infertility (Madsen and Anderson, 1961).

The importance of this finding of subfertility in rheumatoid arthritis is linked with the theories of its aetiology. If, as some believe, the observed familial aggregation of rheumatoid arthritis is due to an inherited predisposition, and if women predisposed to this disease are subfertile, rheumatoid arthritis should be a disappearing disease. Since rheumatoid arthritis is not disappearing, predisposition to it, if familial, must be balanced by some inherited factor favouring increased survival of the smaller number of babies born to women predisposed 
to arthritis. Increased immune resistance to fatal infections of infancy and childhood is one possibility now under investigation.

\section{Summary}

A controlled study is reported of fertility and related factors in 209 women before and after the development of rheumatoid arthritis.

Fertility was found to be lowered before and after the onset of the disease, and the menopause occurred earlier in those destined to develop rheumatoid arthritis than in control subjects.

We are indebted to Dr. Barbara Ansell, Dr. A. St. J. Dixon, and Dr. James Tanner for advice and criticism; to Sir Austin Bradford Hill and Mr. Michael Curwen for statistical guidance; to Miss Pamela Coates and Mrs. M. Wright for help with interviews; and to the Staff of the Rheumatism Unit at St. Stephen's Hospital for their co-operation. We also wish to thank doctors from whose lists the controls were selected.

This work was supported by grants from the British Rheumatic and Arthritis Association and the Research Fund of the Chelsea and Kensington Hospital Group.

During part of this time one of us (A.K.) was receiving a grant from the Arthritis and Rheumatism Council.

\section{REFERENCES}

Ellis, F. A., and Bereston, E. S. (1952). A.M.A. Arch. Derm. Syph., 65, 170.

Friedman, E. A., and Rutherford, J. W. (1956). Obstet. and Gynec., 8, 601 .

Garsenstein, M., Pollak, V. E., and Kark, R. M. (1962). New Engl. J. Med., 267, 165.
Gray, P. G., Corlett, T., and Frankland, P. (1950). "The Register of Electors as a Sampling Frame Social Survey." Central Office of Information, Nov. 1950. H.M.S.O., London.

,-- , and Jones, P. (1951). "The Proportion of Jurors as an Index of the Economic Status of a District”. Central Office of Information, Sept. 1951. H.M.S.O., London.

Hargreaves, E. R. (1958). Ann. rheum. Dis., 17, 61.

Madsen, J. R., and Anderson, G. V. (1961). Obstet. and Gynec., 18, 492.

Ropes, M. W., Bennett, G. A., Cobb, S., Jacox, R., and Jessar, R. A. (1959). Ann. rheum. Dis., 18, 49.

Turner, S. J., LeVine, L., and Rothman, A. (1955). Amer. J. Obstet. Gynec., 70, 102.

Subfertilité avant et après le développement de l'arthrite rhumatismale chez la femme

\section{RÉSUMÉ}

On rapporte une étude contrôlée de la fertilité et des facteurs associés, effectuée chez 209 femmes avant et après le développement de l'arthrite rhumatismale.

On a trouvé que la fertilité était diminuée avant et après le commencement de la maladie, et que la ménopause survenait plus tôt chez celles destinées au développement de l'arthrite rhumatismale que chez les témoins.

\section{Subfertilidad antes y después del desarrollo de la artritis reumatoide en mujeres}

SUMARIO

Se relata una investigación controlada de la fertilidad y de factores asociados en 209 mujeres antes y después del desarrollo de la artritis reumatoide.

La fertilidad fué disminuida antes y después del comienzo de la enfermedad y la menopausia ocurría más temprano en aquellas destinadas a desarrollar la artritis reumatoide que en las testigos. 